\section{Fatiga de vigilancia (fatigatio vigilantiae) durante epidemias}

\section{Daniel Romero-Álvarez, A. Townsend Peterson y Luis E. Escobar}

\section{Surveillance fatigue (fatigatio vigilantiae) during epidemics}

This manuscript presents the concept of "surveillance fatigue" (fatigatio vigilantiae), to describe an epidemiological scenario of an evident underreporting of cases during overwhelming epidemics. We revised past epidemics and found that surveillance fatigue is a common pattern, thus, it may be a useful concept in modern epidemiology.

Key words: Epidemics; epidemiology; fatigatio vigilantiae; surveillance fatigue.

Palabras clave: Epidemias; epidemiología; fatigatio vigilantiae; fatiga de vigilancia.

\section{Introducción}

La recolección, interpretación e intercambio de información sobre enfermedades con los organismos de salud se ha denominado vigilancia epidemiológica. Los datos de vigilancia pueden evolucionar en hipótesis de causalidad y correlación, pero también en predicciones sobre las que pueden basarse estrategias preventivas. Por ejemplo, al inicio de la epidemia del virus Zika en 2016, los datos epidemiológicos iniciales permitieron el desarrollo de sistemas de alerta tempranos ${ }^{1}$. Sin embargo, la vigilancia epidemiológica pasiva y activa puede verse comprometida, especialmente en los países en desarrollo ${ }^{2,3}$.

\section{Descripción de caso}

Presentamos el concepto de fatiga de vigilancia ${ }^{4}$, ofatigatio vigilantiae, definido como el reporte incompleto de casos durante o después de períodos de alta incidencia de enfermedad durante un brote o epidemia. Este subreporte ocurrirá a menudo en las epidemias abrumadoras que sobrecargan al personal y los recursos de las instituciones de salud. Evidentemente, esa sub-notificación sistémica puede conducir a la toma de decisiones incorrectas que afectan la eficacia de las intervenciones de salud pública ${ }^{5}$.

\footnotetext{
Hospital General Enrique Garcés, Quito, Ecuador. Unidad de Epidemiología (DRA). University of Kansas, Lawrence, Kansas, USA. Biodiversity Institute (ATP). University of Minnesota, St. Paul, Minnesota, USA. Department of Fisheries, Wildlife and Conservation Biology (LEE).
}

Conflicto de intereses. Los autores declaran la ausencia de conflictos de interés. Fuente de financiamiento: Este manuscrito no fue financiado por ningún fondo.

Recibido: 5 de agosto de 2016 / Aceptado: 14 de marzo de 2017

Correspondencia a:

Luis E. Escobar

lescobar@umn.edu

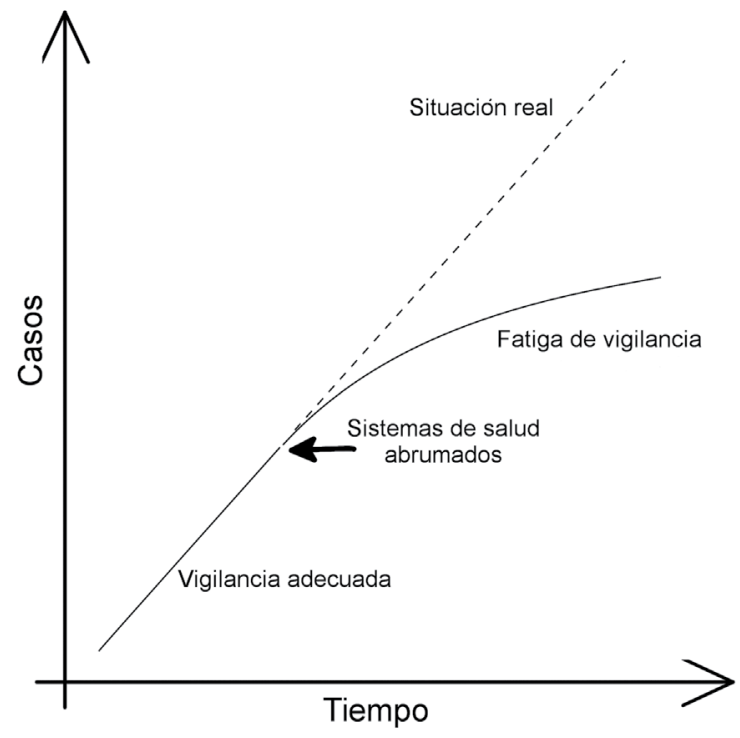

Figura 1. Ejemplo de fatiga de vigilancia. El número acumulado de casos reportados en la etapa inicial de una epidemia puede reflejar el número de casos correctamente (línea recta continua). A medida que el tiempo pasa, la eficacia de la notificación de casos disminuye debido, por ejemplo, a la escasez de personal o suministros de laboratorio y al elevado número de pacientes que abruman los sistemas de salud (flecha). Esto puede resultar en un número incompleto de casos reportados (línea de curva continua), que no refleja el número real de casos (línea discontinua).

Como ejemplo, la explosiva epidemia de Chikungunya en las Américas en 2014 provocó que los sistemas de salud no pudieran detectar y reportar todos los casos por país por semana ${ }^{4}$, demostrando una evidente meseta en la notificación de la enfermedad, especialmente en países con sistemas de vigilancia débiles. Así, el número de casos de Chikungunya no reflejó el tamaño de la epidemia. Desatender esta fatiga de la vigilancia mientras se crean índices epidemiológicos como la incidencia o el riesgo de letalidad provoca una apreciación errónea de la magnitud de la epidemia ${ }^{6}$.

Estudios epidemiológicos al comienzo de una epidemia podrían reflejar correctamente el número de personas infectadas (Figura 1), pero limitaciones posteriores en los suministros de laboratorio o del personal pueden conducir a fatiga de vigilancia. Por ejemplo, en la pandemia de influenza A H1N1 en 2009, países con sistemas de vigilancia fuertes tuvieron dificultades para mantener un informe preciso de los casos debido a sus características abrumadoras; en este escenario, los suministros de diagnóstico de laboratorio fueron consumidos antes del pico de la epidemia, socavando la vigilancia?.

Durante la epidemia de Ébola en 2014, una sub-estimación de casos en Liberia fue claramente identificada y descrita en los informes de la Organización Mundial de la Salud ${ }^{8}$. La disminución de la incidencia se catalogó como "poco probable que fuera genuina" debido a la notable evidencia de sub-notificación ${ }^{8}$. Durante el brote de fiebre amarilla en Angola en 2016, las notificaciones de casos locales se retrasaron incluso con una vigilancia local eficaz y con el apoyo internacional'. 


\section{Discusión}

Las decisiones basadas en los datos de vigilancia sesgada, que no consideren la fatiga de vigilancia, pueden informar en forma incorrecta sobre la verdadera magnitud del número de infecciones en una epidemia. Lipsitch y cols., en el año 2009 propusieron una forma alternativa para dar cuenta de la notificación de casos durante las epidemias: identificar una muestra de la población a ser monitoreada estrictamente por las instituciones de salud en localidades centinelas y luego desarrollar un parámetro de corrección para una estimación precisa de los casos posteriores ${ }^{10}$. Aunque este método necesita una evaluación robusta, puede mitigar la fatiga de la vigilancia mediante la corrección del número de notificaciones durante las epidemias y podría ayudar a asignar recursos efectivamente incluso en escenarios de fatiga de vigilancia ${ }^{10}$.

La epidemiología moderna se enfrenta a cambios dramáticos en la distribución e incidencia de las enfermedades infecciosas. Estos cambios pueden estar asociados con una alta densidad de población, una mayor conectividad entre los países y cambios en el uso de la tierra. En epidemiología, nuevos conceptos son necesarios para representar patrones de enfermedad en un mundo cambiante para tener un marco conceptual actualizado entre los profesionales de la salud.

Agradecimientos. Los autores agradecen a Dennis Guerra-Centeno por su revisión del latín y a Huijie Qiao por la discusión del término.

\section{Resumen}

Se presenta el concepto de "fatiga de vigilancia" (fatigatio vigilantiae) para describir un escenario epidemiológico en el que es evidente el subreporte de casos durante epidemias abrumadoras. Revisamos epidemias pasadas y encontramos que la fatiga de vigilancia es un patrón común, por lo tanto, puede ser un concepto útil en la epidemiología moderna.

\section{Referencias bibliográficas}

1.- Broutet N, Krauer F, Riesen M, Khalakdina A, Almiron M, Aldighieri S, et al. Zika virus as a cause of neurologic disorders. N Engl J Med 2016; 374 : 1506-9.

2.- Nsubuga P, White M E, Thacker S B, Anderson M A, Blount S B, Broome $\mathrm{C} \mathrm{V}$, et al. Chapter 53: Public health surveillance: a tool for targeting and monitoring interventions. Jamison D T, Breman J G, Measham A R, et al. editors. Disease control priorities in developing countries, 2nd ed. Washington, DC, USA: World Bank and Oxford University Press; 2006, p. 997-1015.

3.- Hitchcock P, Chamberlain A, Van Wagoner M, Inglesby T V, O'Toole T. Challenges to global surveillance and response to infectious disease outbreaks of international importance. Biosecur Bioterror 2007; 5: 206-27.

4.- Escobar L E, Qiao H, Peterson A T. Forecasting Chikungunya spread in the Americas via data-driven empirical approaches. Parasit Vectors 2016; 9: 112.

5.- Frieden T R. Government's role in protecting health and safety. N Engl J Med 2013; 368: 1857-9.

6.- $\quad$ Atkins K E, Wenzel N S, Ndeffo-Mbah M, Altice F L, Townsend J P, Galvani A P. Under-reporting and case fatality estimates for emerging epidemics. Br Med J 2015; 350: h1115.

7.- $\quad$ Briand S, Mounts A, Chamberland M. Challenges of global surveillance during an influenza pandemic. Public Health 2011; 125: 247-56.

8.- World Health Organization. WHO: Ebola Response Roadmap Situation Report-8 October 2014. WHO 2014: 1-10. http://apps.who.int/iris/ bitstream/10665/136020/1/roadmapsitrep_8Oct2014_eng.pdf (accessed May 7, 2016).

9.- Rossetto E V, Luna E J. Reporting delay during the yellow fever outbreak, Angola. Rev Inst Med Trop São Paulo 2016; 58: 91.

10.- Lipsitch M, Hayden F G, Cowling B J, Leung G M. How to maintain surveillance for novel influenza A H1N1 when there are too many cases to count. Lancet 2009; 374: 1209-11. 


\section{Surveillance fatigue (fatigatio vigilantiae) during epidemics}

\section{Daniel Romero-Álvarez, A. Townsend Peterson and Luis E. Escobar}

\section{Fatiga de vigilancia (fatigatio vigilantiae) durante epidemias}

Se presenta el concepto de "fatiga de vigilancia" (fatigatio vigilantiae) para describir un escenario epidemiológico en el que es evidente el sub-reporte de casos durante epidemias abrumadoras. Revisamos epidemias pasadas y encontramos que la fatiga de vigilancia es un patrón común, por lo tanto, puede ser un concepto útil en la epidemiología moderna.

Palabras clave: Epidemias; epidemiología; fatigatio vigilantiae; fatiga de vigilancia.

Key words: Epidemics; epidemiology; fatigatio vigilantiae; surveillance fatigue.

\section{Introduction}

The collection, interpretation, and sharing of disease information to health agencies has been termed epidemiological surveillance. Surveillance data can evolve into hypotheses of causation and correlation but also in forecasts on which preventive strategies can be based. For example, at the beginning of the Zika virus epidemic in 2016, initial epidemiological data informed early warning systems ${ }^{1}$. However, passive and active epidemiological surveillance can be compromised, especially in developing countries $^{2,3}$.

\section{Case description}

We present the concept of surveillance fatigue ${ }^{4}$, or fatigatio vigilantiae, defined as incomplete reporting of cases during or after periods of high disease incidence during an outbreak or epidemic. This underreporting will often occur in burgeoning epidemics that overload staff and resources of health institutions. Strikingly, such systemic underreporting may lead to incorrect decisions, affecting effectiveness of public health

\footnotetext{
Hospital General Enrique Garcés, Quito, Ecuador. Unidad de Epidemiología (DRA). University of Kansas, Lawrence, Kansas, USA. Biodiversity Institute (ATP). University of Minnesota, St. Paul, Minnesota, USA. Department of Fisheries, Wildlife and Conservation Biology (LEE).
}

Declaration of interests: The authors declare that there is no conflict of interest

Funding: This manuscript was not supported by any funding.

Authors agree with the publication of the present manuscript.

Recibido: 5 de agosto de 2016 / Aceptado: 14 de marzo de 2017

Correspondencia a:

Luis E. Escobar

lescobar@umn.edu

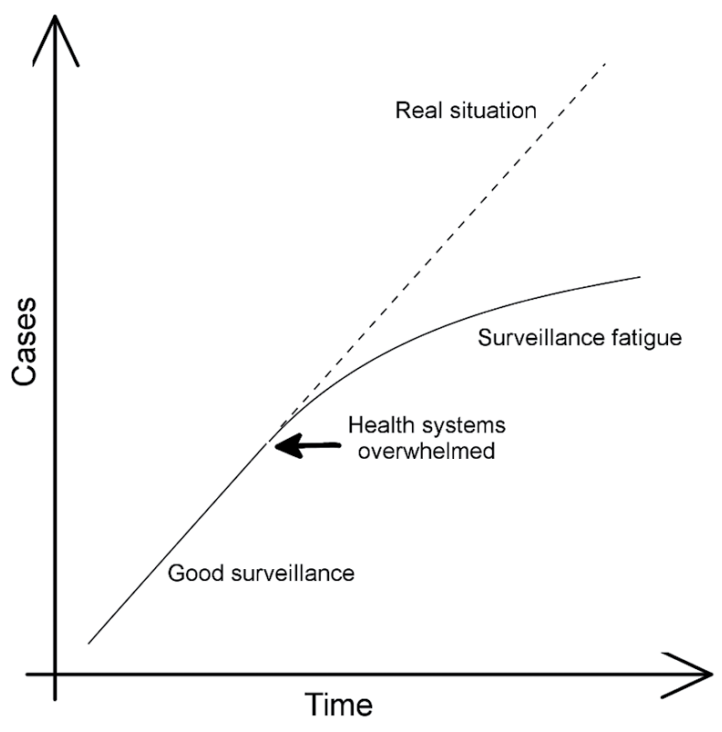

Figure 1. Example of surveillance fatigue. The accumulative number of disease cases reported at the initial stage of an ongoing epidemic may reflect the number of cases properly (continuous straight line). As the time continues, the efficacy of case reporting decrease due to, for example, limited staff or laboratory supplies and high number of patients overwhelming health systems (arrow). This can result in incomplete number of cases reported (continuous curve line), not reflecting real number of cases (dashed line).

interventions ${ }^{5}$. As an example, the explosive epidemic of Chikungunya in the Americas in 2014 resulted in health systems unable to detect and report all cases per country per week ${ }^{4}$, with an evident plateau in disease notification especially in countries with weak surveillance systems. Thus, numbers of Chikungunya cases did not reflect the size of the epidemic. Neglecting surveillance fatigue while building epidemiological indexes such as incidence or case fatality risk could mislead the magnitude of the epidemic ${ }^{6}$.

Epidemiological studies at the beginning of an epidemic could correctly reflect numbers of people infected (Figure 1), but posterior limitations in laboratory supplies or personnel can lead to surveillance fatigue. For example, in the pandemic of influenza A H1N1 in 2009, countries with strong surveillance systems faced difficulties to maintain accurate case reporting due to overwhelming epidemic; in this scenario, laboratory diagnosis supplies were consumed before the peak of the epidemic, undermining surveillance ${ }^{7}$.

During the Ebola epidemic in 2014, an underestimation of cases in Liberia was clearly identified and described in reports of the World Health Organization ${ }^{8}$. Such decrease of incidence was catalogued as 'unlikely to be genuine' due to noticeable evidence of underreporting ${ }^{8}$. During the yellow fever outbreak in Angola in 2016, local case notifications were delayed even with effective local surveillance and international support ${ }^{9}$. 


\section{Discussion}

Decisions based on biased surveillance data, without considering surveillance fatigue, would incorrectly inform the true magnitude of infections. Lipsitch et al. (2009), proposed an alternative way to account for case reporting during epidemics: identify a sample of the population to be strictly monitored by health institutions in sentinel localities, then develop a correction parameter for an accurate estimation of posterior cases $^{10}$. Although this method needs robust evaluation, it can mitigate surveillance fatigue by correcting the number of disease reports during epidemics and could help to effectively allocate resources even in scenarios of surveillance fatigue ${ }^{10}$.

Modern epidemiology is facing dramatic changes in the distribution and incidence of infectious diseases. These changes may be associated with high population density, increased connectivity among countries, and land cover change. In epidemiology, new concepts are necessary to represent disease patterns in a changing world, to maintain an updated conceptual framework among health professionals.

Acknowledgements. Authors thank Dennis Guerra-Centeno for his advice in Latin and Huijie Qiao for discussion of the term.

\footnotetext{
Abstract

This manuscript presents the concept of "surveillance fatigue" (fatigatio vigilantiae), to describe an epidemiological scenario of an evident underreporting of cases during overwhelming epidemics. We revised past epidemics and found that surveillance fatigue is a common pattern, thus, it may be a useful concept in modern epidemiology.
}

\section{References}

1.- Broutet N, Krauer F, Riesen M, Khalakdina A, Almiron M, Aldighieri S, et al. Zika virus as a cause of neurologic disorders. N Engl J Med 2016; 374 : 1506-9.

2.- Nsubuga P, White M E, Thacker S B, Anderson M A, Blount S B, Broome $\mathrm{C} \mathrm{V}$, et al. Chapter 53: Public health surveillance: a tool for targeting and monitoring interventions. Jamison D T, Breman J G, Measham A R, et al. editors. Disease control priorities in developing countries, 2nd ed. Washington, DC, USA: World Bank and Oxford University Press; 2006, p. 997-1015.

3.- Hitchcock P, Chamberlain A, Van Wagoner M, Inglesby T V, O'Toole T. Challenges to global surveillance and response to infectious disease outbreaks of international importance. Biosecur Bioterror 2007; 5: 206-27.

4.- Escobar L E, Qiao H, Peterson A T. Forecasting Chikungunya spread in the Americas via data-driven empirical approaches. Parasit Vectors 2016; 9: 112.

5.- Frieden T R. Government's role in protecting health and safety. N Engl J Med 2013; 368: 1857-9.

6.- Atkins K E, Wenzel N S, Ndeffo-Mbah M, Altice F L, Townsend J P, Galvani A P. Under-reporting and case fatality estimates for emerging epidemics. Br Med J 2015; 350: h1115.

7.- Briand S, Mounts A, Chamberland M. Challenges of global surveillance during an influenza pandemic. Public Health 2011; 125: 247-56.

8.- World Health Organization. WHO: Ebola Response Roadmap Situation Report-8 October 2014. WHO 2014: 1-10. http://apps.who.int/iris/ bitstream/10665/136020/1/roadmapsitrep_8Oct2014_eng.pdf (accessed May 7, 2016).

9.- Rossetto E V, Luna E J. Reporting delay during the yellow fever outbreak, Angola. Rev Inst Med Trop São Paulo 2016; 58: 91.

10.- Lipsitch M, Hayden F G, Cowling B J, Leung G M. How to maintain surveillance for novel influenza A H1N1 when there are too many cases to count. Lancet 2009; 374: 1209-11. 